\title{
As artimanhas do ser e do espaço em "Os cimos", de Guimarães Rosa
}

\author{
Ozíris Borges Filho \\ Ana Carolina de Picoli de Souza Cruz
}

\begin{abstract}
Resumo: O presente trabalho tem por objetivo analisar a construção do espaço no conto "Os cimos", último do livro Primeiras estórias, de Guimarães Rosa. Nosso escopo é determinar como a construção do espaço, feita pelo narrador, homologa ou não os percursos temáticos e influencia a construção do ser da personagem principal. A metodologia que utilizaremos é a da topoanálise, mais as propostas de alguns teóricos como Bachelard e Cassirer. Os espaços da intimidade, de dualidade entre o grande e o pequeno, o interno e o externo do ser, bem como a projeção desses espaços "no" e "pelo" outro são alguns dos pontos discutidos no desenvolvimento deste trabalho.

Palavras-chave: Topoanálise; Espaço; Cenário; Paisagem; Ambiente.

Abstract. This paper aims to examine the construction of space in the short story "Os cimos", the last short story of Primeiras estórias by Guimarães Rosa. The aim is to determine whether the construction of space validates or not the thematic pathways of the story and influences the construction of the main character. The topoanalysis methodology was used for the study as well as the proposals of Bachelard and Cassirer. The space of intimacy, the duality between large and small, internal and external, and the projection of these spaces are some of the points discussed in the paper.

Keywords. Topoanalysis; Space; Scenery; Landscape; Environment.
\end{abstract}

Introdução

Para este trabalho, utilizamos a versão de "Os cimos" que aparece nas referências bibliográficas. Esse conto narra a história de um Menino (mesmo personagem da narrativa "As margens da alegria", primeiro conto do livro Primeiras estórias) em uma outra viagem para o mesmo lugar. O narrador reinventa a cidade artisticamente pelos olhos de uma criança. A escolha não poderia ser melhor para enfatizar as descobertas e as possibilidades criadoras que um espaço em construção proporciona no que diz respeito tanto ao aspecto físico/real quanto ao simbólico/imaginário.

Se a literatura pode ser considerada uma investigação do homem e de suas relações com o mundo, e se o espaço é uma imagem resultante da interpretação

\footnotetext{
*** Ozíris Borges, Prof. Dr. Universidade Federal do Triângulo Mineiro - UFTM. oziris@oziris.pro.br *** Ana Carolina de Picoli de Souza Cruz, Profa. Ms. Centro Universitário Moura Lacerda - CUML. anacarolpsc@yahoo.com.br
} 
do sujeito imaginante, a topoanálise, nesse conto, ganha relevância para o enriquecimento dos estudos sobre a obra de Guimarães Rosa. Segundo Ernest Cassirer,

"[...] devemos analisar as formas da cultura humana para podermos descobrir o verdadeiro caráter do espaço e do tempo no nosso mundo humano. [...] há diferentes tipos de experiência espacial e temporal. Nem todas as formas de experiência estão no mesmo nível. Existem camadas superiores e inferiores, arranjadas de uma determinada maneira." (CASSIRER, 2001, p. 74)

Assim, Cassirer divide o espaço e o tempo em orgânico, perceptual, simbólico ou abstrato e, sobre esse último, diz que "[...] no caso do espaço abstrato, não estamos lidando com a verdade das coisas, e sim, com a verdade de proposições e juízos.” (CASSIRER, 2001, p. 77)

Ora, dado o contexto em que a obra foi escrita e visto que o protagonista é apresentado pelo narrador com um elevado grau de densidade psicológica e suas experiências são também apresentadas nos planos orgânico, perceptual e simbólico, temos uma espacialização a ser analisada.

Outro objetivo deste trabalho é, então, acompanhar a maneira como o narrador mostra os espaços exteriores e interiores, visto que eles funcionam como uma projeção do estado momentâneo da personagem principal. Os espaços físico e subjetivo/simbólico são analisados mutuamente, pois não há como dissociá-los: é por meio desse processo de espelhamento entre espaço e personagem que o texto e o ser do protagonista vão sendo construídos. Para Borges Filho, cabe ao topoanalista observar:

"[...] de que forma as personagens, narrador, eu-lírico, etc. percebem os espaços onde vivem. [...] Antes mesmo de perceber o espaço, o ser ficcional já possui valores que enformam sua percepção espacial. [...] E, a partir dessa percepção, há atitudes, posicionamentos, ações, movimentos que são, basicamente, uma postura cultural." (BORGES FILHO, 2007, p. 118)

\footnotetext{
Por espacialização entende-se aqui a forma como o espaço é instaurado dentro do texto. Há três possibilidades de espacialização. A primeira se dá quando o espaço é construído pelo discurso do narrador. A segunda, quando a personagem descreve o espaço. Finalmente, a terceira ocorre quando o espaço aparece juntamente com a ação da personagem. (BORGES FILHO, 2007) 
O conto ora em foco é segmentado em quatro partes, a saber: "O inverso afastamento", "Aparecimento do pássaro", "O trabalho do pássaro" e "O desmedido momento". Seguiremos a análise de cada uma delas.

\section{O Inverso Afastamento}

Nesta primeira divisão do conto, é importante salientar como o título possui conotações espaciais. Trata-se de um oxímoro espacial na medida em que afastamento implica o distanciamento de um espaço próximo (o aqui) para um espaço longe (o lá). No entanto, como se trata de um inverso afastamento, é como se ao sair do espaço aqui, mais próximo do aqui o sujeito se encontrasse. É justamente esse paradoxo espacial que marca essa primeira parte do conto. O protagonista afasta-se fisicamente de sua casa, deslocando-se no eixo da prospectividade que, segundo a topoanálise, divide-se nos pares longe/perto, aqui/lá. No entanto, mais próximo de si ele se encontra do ponto de vista da construção do seu ser. Portanto, temos aqui indiciada já no título a grande dialética que marca todo o texto: o objetivo versus o subjetivo.

O narrador, hetero e extradiegético, segundo a terminologia de Genette (1977), inicia a história remetendo o leitor ao primeiro conto do livro Primeiras estórias, intitulado "As margens da alegria", mostrando o mesmo personagem (Menino), em uma viagem para o mesmo espaço (cidade em construção), mas por um motivo diferente: "Outra era a vez. De sorte que o Menino viajava para o lugar onde as pessoas faziam a grande cidade. Vinha, porém, só com o Tio, e era uma íngreme partida. Entrara aturdido no avião [...] Sabia que a mãe estava doente. Por isso o mandavam para fora [...].” (ROSA, 2001, p. 224)

Notamos, no trecho acima, a presença de três coordenadas espaciais: verticalidade, prospectividade e interioridade. A primeira marca o deslocamento do Menino do baixo para o alto, daí o uso das figuras "íngreme partida", do espaço térreo para o espaço suspenso. A segunda coordenada espacial, representada pelo eixo da prospectividade, divide-se na dialética entre perto e longe, aqui e lá. Desse ponto de vista, o Menino desloca-se do perto, do aqui, e vai para o lá, para o longe, que, no texto, é representado pela grande cidade que está sendo feita. Também nesse deslocamento o protagonista, ao adentrar o avião, desloca-se da exterioridade. Ao ocupar essa nova espacialidade ele também é marcado, para além do eixo da interioridade, pelo eixo da amplitude. Nesse sentido, trata-se de um espaço restrito, fechado. Toda essa 
espacialidade construída no texto homologa a temática proposta. Nesse sentido, cumpre destacar dois aspectos importantes: o primeiro com relação ao lugar para onde o Menino irá se deslocar e o segundo com relação ao modo como ele se desloca (em um avião). A ideia de ir para um lócus em construção, que ainda não está pronto, que é, na verdade, uma imagem que está se moldando, ou uma ideia suspensa, aliada ao espaço suspenso que o avião percorre e à tentativa do menino de reter o tempo perdido (com sua Mãe) são estratégias que o narrador utiliza para enfatizar a ideia da construção do espaço a partir da visão do sujeito da ação, quer dizer, o espaço físico reflete o espaço subjetivo e vice-versa. Assim, os espaços suspensos apresentados reiteram a ideia de um devir, de uma constante transformação, de um vir-a-ser.

Por meio das coordenadas espaciais citadas, o narrador acompanha a viagem do Menino e dá indícios de que essa viagem não se realizará apenas no plano físico. Ao mesmo tempo em que inicia uma jornada no espaço real, o protagonista também inicia uma jornada no espaço interior/simbólico.

Sobre essa relação entre exterior e interior, Bachelard afirma o seguinte:

"O exterior e o interior formam uma dialética de esquartejamento [...] Ela tem a nitidez crucial da dialética do sim e do não, que tudo decide. Fazemos dela, sem o percebermos, uma base de imagens que comandam todos os pensamentos do positivo e do negativo. [...] O filósofo, com o interior e o exterior, pensa o ser e o não ser. A metafísica mais profunda está assim enraizada numa geometria implícita, numa geometria que queiramos ou não - espacializa o pensamento [...]." (BACHELARD, 2005, p. 215)

Reiterando esses indícios, nota-se que a espacialização é franca, pois o narrador onisciente é quem descreve o espaço tanto físico quanto subjetivo do protagonista. Há que se destacar, portanto, a função desse narrador que, segundo Paulo Rónai, "existe para decifrar os pensamentos hieroglíficos do Menino" (RÓNAI, 2001). Partindo dessa afirmação de Rónai, é importante destacar que o narrador propõe sutilmente ao leitor que também decifre esses pensamentos. E, sem dúvida, o estudo do espaço é ferramenta fundamental para esse decifrar. 
As artimanhas do ser e do espaço em Os Cimos. A metáfora e o ser

A seguir, encontramos o seguinte trecho:

"Soubesse que um dia a Mãe tinha de adoecer, então teria ficado sempre junto dela, espiando para ela, com força, ah. [...] Do jeito feito agora, no coração do pensamento. Como sentia com ela, mais do que se estivessem juntos, mesmo, de verdade.

[...] O avião então estivesse parado voando - e voltando para trás, mais, e ele junto com a Mãe, do modo que nem soubera, antes, que o assim era possível." (ROSA, 2001, p. 226)

Nesse excerto, tem-se o contraste entre o tempo e o espaço. O agora está ligado ao real, ao espaço físico em que o protagonista se encontra, mas em seu espaço subjetivo o Menino se volta para "trás", para o "seu" espaço natural, que não é o mesmo em que se encontra no agora. Isso estabelece uma relação entre tempo e espaço: o espaço físico/real está ligado ao tempo presente, ao agora, enquanto o espaço interior/simbólico está ligado ao passado, ou àquilo que foi deixado pelo Menino. Além disso, é possível perceber que o espaço vai sendo construído a partir do entrelaçamento de vários planos espaço-temporais que foram vivenciados pelo protagonista. Portanto, o espaço apresenta-se com um caráter múltiplo que é constantemente rearranjado pela memória. Citando Bachelard:

"Nesse teatro do passado que é a memória, o cenário mantém os personagens em seu papel dominante. Por vezes acreditamos conhecer-nos no tempo, ao passo que se conhece apenas uma série de fixações nos espaços da estabilidade do ser, de um ser que não quer passar no tempo; que no próprio passado, quando sai em busca do tempo perdido, quer "surpreender" o voo do tempo. Em seus mil alvéolos, o espaço retém o tempo comprimido. É essa a função do espaço." (BACHELARD, 2005, p. 28)

Outro ponto de investigação consiste em descobrir o que está ocorrendo no espaço da intimidade do protagonista. Há um processo de espelhamento no "contraste" apresentado entre o espaço e o tempo, pois o Menino carrega consigo o seu "bonequinho macaquinho", seu brinquedo favorito. Além des- 
se espelhamento ou projeção, é possível pensarmos na questão da miniatura proposta por Bachelard:

\begin{abstract}
"A representação não é mais que um corpo de expressões para comunicar aos outros nossas próprias imagens. [...] É preciso compreender que na miniatura os valores se condensam e se enriquecem. Não basta uma dialética platônica do grande e do pequeno para conhecer as virtudes dinâmicas da miniatura. É preciso ultrapassar a lógica para viver o que há de grande no pequeno." (BACHELARD, 2005, p. 159)
\end{abstract}

Assim, a projeção do Menino em seu macaquinho revela um jogo de espelhos com a imagem de dois seres e com os espaços (englobante e englobado) em que eles se encontram: o Menino dentro do avião e o macaquinho dentro de seu bolso; o menino só com ele mesmo (em seu espaço interior) e o macaquinho como "O pobre do macaquinho, tão pequeno, sozinho, tão sem mãe; pegava nele, no bolso, parecia que o macaquinho agradecia, e, lá, dentro, no escuro, chorava." (ROSA, 2001, p. 226)

Essa simbologia apresentada pela metonímia espacial e pelas personagens vem reiterar a ideia do cruzamento dos planos espaço-temporais mostrada pelo narrador por meio do espaço físico e do simbólico; do tempo real e do subjetivo; da imagem do protagonista voltado para si mesmo e refletida no macaquinho.

Dessa forma, nesse primeiro segmento do conto rosiano predomina o cenário, isto é, um espaço produzido pelo homem, oposto à natureza, espaço não criado pelo homem. Nesse cenário, o protagonista inicia seu caminho na construção do próprio eu, no estar processa-se o ser, ou, sartrianamente, a existência precede a essência. O papel temático assumido pelo protagonista é o da agonia, da angústia. Ele se afasta de um ente querido, sua mãe, e nesse afastamento sente-se atordoado com a possibilidade da perda desse outro. É o que Sartre afirma ser a experiência da morte secundária. A possibilidade dessa experiência assusta o menino e o angustia por quase toda a extensão da narrativa.

\title{
2. O Aparecimento do Pássaro
}

"[...] todo o espaço realmente habitado traz a essência da noção de casa."

Gaston Bachelard 
O espaço da casa para onde o Menino vai é apresentado com algumas características que nos chamam a atenção: sua localização e o fato de ela não ter mudado. "Na casa, que não mudara, entre e adiante das árvores, todos começaram a tratá-lo com qualidade de cuidado. Diziam que era pena não haver ali outros meninos." (ROSA, 2001, p. 226)

Destaque-se o fato de o Menino ter ido a outra casa, a casa do Tio, que fica "entre e adiante das árvores." Pensando um pouco sobre a questão da casa, afirma Bachelard: "[a casa é] uma das maiores [forças] de integração para os pensamentos, as lembranças e os sonhos do homem. Nessa integração, o princípio de ligação é o devaneio. [...] A vida começa bem, começa fechada, protegida, agasalhada no regaço da casa." (BACHELARD, 2005, p. 26)

Fica claro assim, que o Menino é retirado de seu "berço", mas é levado a outro espaço que o agasalhará e o protegerá, bem como a seus pensamentos e devaneios. Essa mudança de espaço (de uma casa para outra) nos faz refletir no jogo do exterior/interior que será desenvolvido no decorrer do conto, não apenas no que diz respeito ao espaço físico-real, mas também no tocante ao espaço subjetivo-simbólico. Para Bachelard, "Fechado no ser, sempre há de ser necessário sair dele. Apenas saído do ser, sempre há de ser preciso voltar a ele. Assim, no ser, tudo é circuito, tudo é rodeio, retorno, discurso, tudo é rosário de permanências, tudo é refrão de estrofes sem fim.” (BACHELARD, 2005, p. 217)

Portanto, a ideia de circuito para um crescimento e um acréscimo de experiências que ajudarão o protagonista a amadurecer está colocada por meio do espaço. É importante dizer que essa ideia é reiterada não só no conto como também no livro, Primeiras estórias, visto que este se inicia com um conto sobre o Menino ("As margens da alegria") e termina com outra narrativa sobre ele ("Os cimos"). Rosa homologa, assim, a ideia do circuito. Nessa ideia do circuito, do sair e do voltar a si, não podemos esquecer que, etimologicamente, o termo existencialismo deriva de existência, que, por sua vez, vem do verbo latino existere, que significa "sair de uma casa, domínio, movimento para fora". Portanto, o existencialismo é uma doutrina filosófica que procura analisar o homem a partir de fora. $\mathrm{O}$ homem se desprende para melhor se analisar. Sair-voltar, circuito. Mas essa análise não incide sobre o homem como um ser abstrato. Pelo contrário, a reflexão existencialista centra-se no homem individual e concreto.

O segundo aspecto a ser destacado é em relação à localização dessa casa. Por estar em um local entre e adiante das árvores, que remete a um es- 
paço ligado à natureza, nada nele é artificial, e portanto tudo o que o Menino vivenciar ali - devaneio ou não - será também natural, verdadeiro, terá raízes. $\mathrm{Na}$ verdade, poderíamos pensar na imagem da floresta analisada por Bachelard. Para ele, a floresta está ligada à imensidão e à profundidade interior:

"Essa "imensidão" nasce de um corpo de impressões que não derivam realmente de ensinamentos de geografia. Não é preciso permanecer muito tempo nos bosques para conhecer a impressão sempre um pouco ansiosa de que "mergulhamos" num mundo sem limites. [...] A floresta é um estado de alma." (BACHELARD, 2005, p. 191-92)

Assim, não é por acaso que a casa do Tio se encontra nesse topos. Todo o espaço para o qual o Menino é transportado proporciona a ele uma viagem para a profundidade de si mesmo e momentos de autoconhecimento.

Apesar de a casa se encontrar em um espaço que está sendo transformado, ela se mantém intacta. Essa imagem reitera a força desse espaço natural, acolhedor e, ao mesmo tempo, novo, convidativo para outras vivências que devem partir da personagem principal.

O espaço interno da casa é apresentado como um espaço nebuloso e frio, ligado ao desconhecimento. Temos então uma relação topofóbica entre personagem e espaço. Aparece também, mais uma vez, a ideia de devir, do que está por ser feito, do incerto:

"Mesmo assim, à noite, não começava a dormir. $\mathrm{O}$ ar daquele lugar era friinho, mais fino. Deitado o menino se sentia sustoso, o coração dando muita pancada. [...]

E não podia logo dormir, e pela dita causa. O calado, o escuro, a casa, a noite - tudo caminhava devagar, para o outro dia." (ROSA, 2001, p. 227)

Notamos, portanto, um ambiente nebuloso, solitário no qual o Menino se encontra só com seus pensamentos e revela suas inquietações e preocupações. Agora o único espaço interno da casa apresentado é o do quarto. É como se o narrador conduzisse o leitor (e, ao mesmo tempo, o protagonista) para um mergulho no universo da intimidade. As imagens espaciais criadas vão se 
As artimanhas do ser e do espaço em Os Cimos. A metáfora e o ser

afunilando. No quarto, também ocorre entre o macaquinho e o protagonista um jogo devido à transferência, ao espelhamento e personificação do macaquinho: "O Tio ressonava. O macaquinho, quase também, feito um muito velho menino.” (ROSA, 2001, p. 227)

Assim, quando o Menino se mostra com características próprias dos adultos, ou se comporta como um dos citados (no caso, o Tio), ele se torna um "velho menino". Mais uma vez podemos recorrer a Bachelard:

"É encerrado em sua solidão que o ser de paixão prepara suas explosões ou seus feitos.

E todos os espaços das nossas solidões passadas [...] são indeléveis em nós [...] A eles voltamos nos sonhos noturnos. Esses redutos têm valor de concha." (BACHELARD, 2005, p. 29)

Portanto, "Feliz a criança que possui, que realmente possui as suas solidões." (BACHELARD, 2005, p. 35)

No espaço externo da casa, temos o alpendre, que é um lugar de transição do interior para o exterior, onde o narrador mostra a passagem do tempo (do amanhecer até o sol nascer por completo), e o início de uma transição no pensamento da personagem principal:

"O alpendre era um passadiço, entre o terreirinho mais a mata e o extenso outro-lado - aquele escuro campo, sob rasgos, neblinas, feito um gelo, e os perolins do orvalho: a ir até a fim de vista, à linha do céu de este, na extrema do horizonte. $\mathrm{O}$ sol ainda não viera. Mas a claridade. Os cimos das árvores se douravam. As altas árvores depois do terreiro, ainda mais verdes, do que o orvalho lavara. Entremanhã - e de tudo um perfume, e passarinhos piando. Da cozinha, traziam café." (ROSA, 2001, p. 228)

Aqui há algumas marcas espaço-temporais a serem analisadas, e todas elas representam o tema da transitoriedade. Segundo o narrador, "o alpendre era um passadiço", ou seja, um espaço de transição entre o "terreirinho" e o "escuro campo". Note-se que essa transição se dá também entre espacialidades diferentes, isto é, passa-se do cenário, espaço cultural construído pelo 
homem, para a natureza, espaço não cultural. A transição também marca a temporalidade, pois nesse trecho há a passagem da noite para o dia: "O sol ainda não viera. Mas a claridade." Daí o neologismo entremanhã, que marca bem essa transitoriedade.

Do ponto de vista da topoanálise, analisemos a maneira como o Menino percebe esse espaço. Trata-se aqui de analisarmos os gradientes sensoriais, ou seja, os sentidos humanos por meio dos quais o ser percebe o entorno espacial. No trecho acima citado, vemos a presença da visão, do olfato e da audição. A visão é o gradiente mais explorado. Por meio dela o ser percebe uma grande distância de espaço, as cores que o impregnam e também que "Os cimos das árvores se douravam." É a primeira vez que aparece a palavra cimos, que dá título ao conto. Essa figura, cimos, está marcada pelo eixo da verticalidade, mais especificamente pelo polo do alto. E é nesse alto que também ocorrerá a aparição do pássaro, título deste segmento da narrativa. A partir dessa aparição no alto, ocorrerá um momento de epifania para o protagonista. Parece então que há uma homologação entre o alto físico e a ideia de experiência interior que sofrerá o Menino, um aspecto parece homologar o outro. Assim, retomando o tema da transição, nota-se que ele não marca apenas os dados da experiência externa do protagonista: marca também a experiência interna. É nessa espacialidade bem construída que o Menino sofrerá, por meio da epifania, uma transição de um estado tenso de morbidez, preocupação, angústia para um estado distenso de euforia, alegria. Da transição externa do espaço e do tempo, chega-se à transição interna do Menino. Portanto, espaço, tempo e ser homologam-se, reforçam-se mutuamente:

"E: - "Pst!" - apontou-se. A uma das árvores, chegara um tucano, em brando batido horizontal. Tão perto! O alto azul, as frondes, o alumiado amarelo em volta e os tantos meigos vermelhos do pássaro - depois de seu voo. Seria de ver-se: grande, de enfeites, o bico semelhando flor de parasita. Saltava de ramo em ramo, comia da árvore carregada. Toda a luz era dele, que borrifava-a de seus coloridos, em momentos pulando no meio do ar, estapafrouxo, suspenso esplendentemente. No topo da árvore, nas frutinhas, tuco, tuco... daí limpava o bico no galho." (ROSA, 2001, p. 228)

Nesse primeiro momento, temos a descrição da aparição do pássaro, que é um tucano com a predominância do gradiente sensorial da visão e, daí, 
As artimanhas do ser e do espaço em Os Cimos. A metáfora e o ser

a profusão de cores que impregna o trecho. O esplendor é tanto que o narrador usa o advérbio esplendentemente e a expressão: "Toda a luz era dele..." Observa-se também, mais uma vez, a coordenada espacial da verticalidade, visto que o pássaro está no alto.

O tucano está suspenso e é uma miniatura se comparado ao vasto espaço em que se encontra. A ideia de condensação da beleza é a que o tucano encerra em si, além do fato de que ela vem do alto. Aqui o narrador chama atenção para o detalhe, para o que está acima do plano no qual o Menino se encontra. A epifania do menino é regida pela estesia. A coordenada espacial da verticalidade apresenta o belo, o sublime:

"E, de olhos arregaçados, o Menino, sem poder segurar para si o embrevecido instante, só nos silêncios de um-dois-três. No ninguém falar. Até o Tio. O Tio, também, estava de fazer gosto por aquilo; limpava os óculos. O tucano parava, ouvindo outros pássaros - quem sabe, seus filhotes - da banda da mata. O grande bico para cima, desferia, por sua vez, às uma ou duas, aquele grito meio ferrugento dos tucanos: "Crrée!"... O menino estando nos começos de chorar. Enquanto isso, cantavam os galos. O menino se lembrava sem lembrança nenhuma. Molhou todas as pestanas." (ROSA, 2001, p. 228)

Observe-se como a beleza invade não só o espaço mas também a intimidade das pessoas que o habitam. O cimo e o que há nele envolvem o espaço linear (chão) e levam as pessoas à estese, ao encantamento, ao deleite. $\mathrm{O}$ espaço reflete e, ao mesmo tempo, transforma as personagens. Quem mais desfruta do momento é o Menino. Várias figuras são usadas para caracterizar fisicamente essa personagem e seu momento de epifania: "olhos arregaçados", "começos de chorar", "lembrava sem lembrança", "molhou todas as pestanas". Outro dado que chama a atenção para esse momento de estesia é o neologismo embrevecido. Trata-se da fusão das palavras embevecido e breve. Esse neologismo nos remete a dois temas ligados ao momento epifânico do Menino. O primeiro tema é o do êxtase do momento e o segundo o da brevidade. Ou seja, aquele momento de apreciação da beleza, de descoberta é profundo, mas fugaz. 


\section{O Trabalho do Pássaro}

"E a contemplação da grandeza determina uma atitude tão especial, um
estado de alma tão particular que o devaneio coloca o sonhador fora
do mundo próximo, diante de um mundo que traz o signo do infinito."

Gaston Bachelard

Este terceiro segmento do conto é marcado por estados contraditórios do Menino. De um lado, há a angústia pela possível perda da mãe. De outro, a experiência de ver o tucano que lhe dava a sensação de plenitude. Esse é o trabalho do pássaro a que se refere o título desse segmento: entre a disforia, propiciar um momento de euforia, de escape, de alívio enfim. Esses dois temas já aparecem nos dois primeiros parágrafos.

O primeiro:

"Assim, o menino, entre dia, no acabrunho, pelejava com o que não queria querer em si. Não suportava atentar, a cru, nas coisas, como são, e como sempre vão ficando: mais pesadas, mais-coisas - quando olhadas sem precauções. Temia pedir notícias; temia a mãe na má miragem da doença? Ainda que relutasse, não podia pensar para trás. Se queria atinar com a mãe doente, mal, não conseguia ligar o pensamento, tudo na cabeça da gente dava num borrão. A mãe da gente era a mãe da gente, só; mais nada." (ROSA, 2001, p. 230)

Esse primeiro parágrafo é marcado pelo medo. O Menino não quer que algo ruim aconteça com sua mãe, portanto ele se encontra em um momento tenso, disfórico. Esse é um dos temas que são trabalhados no conto e que fazem parte da construção do próprio ser do Menino.

Já no segundo parágrafo, encontramos um outro dado:

"Mas, esperava; pelo belo. Havia o tucano - sem jaça - em voo e pouso e voo. De novo, de manhã, se endereçando só àquela árvore de copa alta, de espécie chamada mesmo tucaneira. E dando-se o raiar do dia, seu fôlego dourado." (ROSA, 2001, p. 230) 
O segundo parágrafo começa pela conjunção adversativa mas, o que dá a medida de sua relação com o parágrafo anterior. Dessa forma, enquanto o primeiro é marcado pelo medo, este se marca pelo belo. São parágrafos antitéticos. Esse momento no amanhecer era o único que trazia certo alívio ao menino, como prova o primeiro período do terceiro parágrafo: "Depois do encanto, a gente entrava no vulgar inteiro do dia."

Esses dois primeiros parágrafos remetem-nos novamente ao conceito de circuito de Bachelard, já citado anteriormente. O ir e vir do tucano e a contemplação da beleza acontecem em um espaço natural, na mata que cerca a casa. É importante destacar que essa espacialidade da floresta, no caso a mata, está ligada à ideia de além, de imensidão e de transcendência, segundo Bachelard, já citado.

Assim, o topos a ser analisado ganha densidade no texto por ser apropriado ao devaneio, por ser um espaço cuja principal ação, a da contemplação, desenrola-se a partir do alto (o objeto contemplativo está no cimo da árvore) e por ser um lugar que reflete em seu exterior o que ocorre no interior do Menino. $\mathrm{Na}$ verdade, o ir e vir do tucano lembra o ir e vir do Menino no espaço físico (de sua casa para a casa do Tio) e no tempo (seu pensamento, ora no passado com a mãe, ora no presente com o tucano). E é nesse ir e vir físico e metafísico que se desenrola o vir-a-ser do Menino, a sua construção consciencial.

Note-se que o tucano não aparecia em outro horário que não no amanhecer e nem havia ali sinal de um ninho seu. Ele vinha do donde, ou seja, de um lugar indefinível, mas certamente diferente: "De dia, não voltava lá. Se donde vinha e morava - das sombras do mato, os impenetráveis? [...] Mas o Menino pensava que devia acontecer mesmo assim - que ninguém soubesse. Ele vinha do diferente, só donde. O dia: o pássaro.” (ROSA, 2001, p. 231)

Dentre as coordenadas espaciais, há o eixo da prospectividade que se divide em longe versus perto. Esse eixo é um dos que marcam a espacialidade do pássaro. Ele vem de um longe que não se sabe qual é e, no amanhecer, está perto do Menino. Note-se ainda que a aparição do pássaro é marcada pelas coordenadas da interioridade, da amplitude e da verticalidade. Dessa forma, essa aparição acontece sempre em um topos exterior, amplo e alto.

Outro dado nessa parte do conto é o fato de o tio receber um telegrama: "Entremeio, o tio, recebido um telegrama, não podia deixar de mostrar a cara apreensiva - o envelhecimento da esperança. Mas, então, fosse o que fosse, 
o menino, calado consigo, teimoso de só amor, precisava de se repetir: que a mãe estava sã e boa, a mãe estava salva!” (ROSA, 2001, p. 232)

O Menino percebe que a mãe havia piorado e sua primeira atitude é a da negação. O tio, para agradar ao menino, quer aprisionar o tucano para que ele possa desfrutar melhor da companhia do pássaro. Esse fato nos remete ao primeiro conto do livro, em que outro animal, que também desencadeou uma epifania no menino, foi morto. Naquela ocasião, tratava-se de um pavão. Agora, esse desejo do tio causa um grande alarme no menino:

"De repente, ouviu que, para consolá-lo, combinavam maneira de pegar o tucano: com alçapão, pedrada no bico, tiro de espingardinha na asa. Não e não - zangou-se, aflito. O que cuidava, que queria, não podendo ser aquele tucano, preso. Mas a fina primeira luz da manhã, com, dentro dela, o voo exato." (ROSA, 2001, p. 232)

Esse parágrafo tematiza a ideia de gratuidade do fruir estético. $\mathrm{O}$ Menino não queria ser dono do pássaro. $\mathrm{O}$ que valia era justamente a sua liberdade e seus atos gratuitos junto à natureza, em consonância ainda com o amanhecer. Era na conjunção desses fatores que a estesia ocorria. Aprisionar o pássaro seria acabar com a possibilidade do prazer estético gratuito, como é reforçado pelo parágrafo seguinte:

"O hiato - o que ele já era capaz de entender com o coração. Ao outro dia seguinte. Aí, quando o pássaro, seu raiar, cada vez, era um brinquedo de graça. Assim como o sol: daquela partezinha escura no horizonte, logo fraturada em fulgor e feito a casca de um ovo - ao termo da achãada e obscura imensidão do campo, por onde o olhar da gente avançava como no estender um braço.” (ROSA, 2001, p. 232)

Esse parágrafo reforça a ideia de gratuidade e também a espacialidade anteriormente mostrada. Isso se comprova por meio das figuras brinquedo de graça, horizonte e campo.

No entanto, há uma nova ideia que cumpre destacar no excerto acima e que se apresenta no primeiro período do parágrafo. Trata-se da ideia do "hiato". Que hiato seria esse? Segundo o texto, parece que tal hiato se refere justamente ao intervalo contraditório entre as duas experiências do Menino nessa casa em 
que mora com o tio: a angústia pelo estado mórbido da mãe e a epifania pela beleza do pássaro. Em outras palavras, o Menino é marcado pela experiência de morte e de vida. Essa interpretação é reforçada pelo seguinte parágrafo:

\begin{abstract}
"A tornada do pássaro era emoção enviada, impressão sensível, um transbordamento do coração. O menino o guardava, no fugidir, de memória, em feliz voo, no ar sonoro, até a tarde. O de que podia se servir para consolar-se com, e desdolorir-se, por escapar do aperto de rigor - daqueles dias quadriculados." (ROSA, 2001, p. 232)
\end{abstract}

O Menino nega a ideia de perigo que a mãe poderia estar correndo. Daí a frase: "O voo do pássaro habitava-o mais." Ou seja, diante da perda do ente querido, o Menino se apoia ainda mais na experiência estésica que o pássaro lhe propiciava. Diante da morte, ele se apega mais à vida, à "impressão sensível, um transbordamento do coração".

Nesse ponto, a narrativa parece encaminhar-se para um desfecho trágico para o Menino, mas o último parágrafo reverte essa expectativa: "Ao quarto dia, chegou um telegrama. O tio sorriu fortíssimo. A Mãe estava bem, sarada! No seguinte - depois do derradeiro sol do tucano - voltariam para casa." (ROSA, 2001, p. 232)

\title{
4. O Desmedido Momento
}

Se o segmento anterior é marcado pela dialética da vida e da morte, este quarto e último excerto é marcado pela ideia de conciliação. Esse apaziguamento, essa superação da dialética do ser acontece por uma nova consciência, por um novo entendimento que agora o Menino tem da vida. Essa nova cosmovisão decorre de uma transcendência ou, sendo fiel às imagens do texto, de um transbordamento do ser. Com efeito, a principal imagem que ocupa esse segmento é a ideia de sair de si, de transbordar, de superar limites.

Esse segmento narra o retorno do Menino para sua casa e para sua Mãe. Essa volta ocorre em num espaço suspenso, o mesmo que o do início, no mesmo avião. Há, porém, uma mudança radical no modo como o Menino vê esse retorno e analisa os espaços em que viveu: 
"E, com pouco, o Menino espiava, da janelinha, as nuvens de branco esgarçamento, o veloz nada. Entretempo, se atrasava numa saudade, fiel às coisas de lá. Do tucano e do amanhecer, mas também de tudo, naqueles dias tão piores: a casa, a gente, a mata, o jeep, a poeira, as ofegantes noites - o que se afinava, agora, no quase azul do seu imaginar. A vida, mesmo, nunca parava." (ROSA, 2001, p. 233)

A saudade do menino refere-se às coisas de lá, por oposição ao aqui, que é o espaço para onde ele vai. Mesmo deixando o espaço do lá, essa espacialidade o persegue na forma das memórias. Há uma retomada, outrossim, de todos os conceitos já abordados desde o início deste trabalho - a questão da memória enquanto criadora do espaço, do tempo comprimido no espaço, a questão do ir e vir, do circuito e da reflexão sobre o conhecimento de nossos espaços íntimos dada por Bachelard:

"É pelo espaço, é no espaço que encontramos os belos fósseis de duração concretizados por longas permanências. $\mathrm{O}$ inconsciente permanece nos locais. [...] Localizar uma lembrança no tempo não passa de uma preocupação de biógrafos e corresponde praticamente a uma história externa [...] Mais urgente que a determinação das datas é, para o conhecimento da intimidade, a localização nos espaços da nossa intimidade."

(BACHELARD, 2005, p. 29)

Representando todo o processo pelo qual o personagem principal passa, há uma adjetivação importante dada pelo narrador e pela perda do macaquinho, objeto de projeção do Menino: "Entrepensava o Menino, já quase na fronteira soporosa. [...] E, quase num pulo, agoniou-se: o bonequinho macaquinho não estava mais em seu bolso!” (ROSA, 2001, p. 233) A expressão fronteira soporosa está ligada ao inconsciente, ao mundo do quase sonho. Essa fronteira apresentada localiza-se em um espaço suspenso e interior (dentro do avião). Pode-se ainda pensar que ela é em um espaço de transição do protagonista. Reforçando a ideia de entrelaçamento dos planos espaço-temporais e do espelhamento entre espaço e personagem, o narrador cria um jogo de imagens e de sensações que denunciam a travessia do Menino em uma barreira suspensa (no espaço aéreo), tensa (já que há um conflito interno da personagem) e em um espaço simbólico. Há um indício de amadurecimento do Menino dado pela perda de seu bonequinho. O Menino não precisa mais dele, e o narrador mostra que o protagonista fica apenas com a alegria que 
o macaquinho the proporcionava, assim como ficou com o encantamento do pássaro em si. Temos, assim, a prova de que os fósseis de permanência da memória podem modificar e criar espaços e ambientes:

"Mas, então, o moço ajudante do piloto veio trazer-lhe, de consolo, uma coisa: -"Espia, o que foi que eu achei, para Você" - e era, desamarrotado, o chapeuzinho vermelho, de alta pluma, que ele, outro dia, tanto tinha jogado fora!

[...] Não. O companheiro macaquinho não estava perdido, no sem-fundo escuro do mundo, nem nunca. Decerto, ele só passeava lá, porventuro e porvindouro, na outra-parte, aonde as pessoas e as coisas sempre iam e voltavam." (ROSA, 2001, p. 233)

Talvez o circuito a que nos remete o narrador na verdade se encerre nessa parte, quando o objeto alegre do bonequinho é devolvido ao Menino, que, então, reflete: "E era o inesquecível de-repente, de que podia traspassar-se, e a calma, inclusa. [...] e em toda-a-parte... no mesmo instante só...” (ROSA, 2001, p. 233). Note-se o trabalho do narrador com os espaços em que se dão as ações reflexivas do protagonista. Esses espaços estão sempre no alto, ou suspensos, ou em espaços naturais, ou mesmo em espaços íntimos, como o quarto. É como se o Menino estivesse em trânsito permanente por si mesmo, percorrendo sua intimidade.

Outro ponto importante no trecho transcrito acima se refere à cosmovisão a que o Menino chega. Parece que a concepção de mundo é circular, nada morre efetivamente, tudo volta, como o macaquinho. Portanto, mesmo que a mãe viesse a desaparecer no futuro, o Menino não se sentiria de todo preocupado, pois sabia que um dia a mãe retornaria, como o macaquinho, que “[...] não estava perdido, no sem-fundo escuro do mundo, nem nunca." É assim que o Menino resolve o conflito do ser perante a morte. Esse é o salto consciencial do protagonista ao fim deste conto. É por isso que sua fala final é enigmática:

\footnotetext{
“_- "Chegamos, afinal!" - o Tio falou.

- “Ah, não. Ainda não..." - respondeu o Menino. 
Sorria fechado: sorrisos e enigmas, seus. E vinha a vida." (ROSA 2001, p. 234)

Enquanto o tio se refere ao físico, a resposta do Menino parece levar em conta o metafísico. A viagem física da casa do tio para a casa do Menino havia terminado, mas não a viagem que o Menino começa a empreender pelos mistérios universais do ser humano. Nesses, ele só estava começando...

\section{Referências}

CASSIRER, Ernest. Ensaio sobre o homem. São Paulo: Martins Fontes, 2001.

BACHELARD, Gaston. A poética do espaço. São Paulo: Martins Fontes, 2005.

BORGES FILHO, Ozíris. Espaço e literatura: introdução à topoanálise. Franca: Ribeirão Gráfica Editora, 2007.

; BARBOSA, Sidney. Poéticas do espaço literário. São Carlos: Claraluz, 2009.

GENETTE, Gérard. Discurso da narrativa. Lisboa: Vega, 1977.

ROSA, João Guimarães. Primeiras estórias. Rio de janeiro: Nova Fronteira, 2001.

RÓNAI, Paulo. Os vastos espaços. In: ROSA, João Guimarães. Primeiras estórias. Rio de janeiro: Nova Fronteira, 2001.

Recebido para publicação em 20 de junho de 2009. Aceito para publicação em 08 de março de 2010. 